\title{
Study on Innovation and Entrepreneurship Ability Training System for Students in Information Science
}

\author{
Hui Wang \\ School of Beijing City University, Beijing 100083, China
}

bcuwhui@126.com

\begin{abstract}
In this paper, the current situation of and existing problems in innovation and entrepreneurship education for students in information science and affecting their innovation and entrepreneurship ability are analyzed, based on which the innovation and entrepreneurship ability training system for students in information science is established.
\end{abstract}

Keywords: information specialty; innovation and entrepreneurship ability; cooperative training

\section{Introduction}

Colleges and universities are required to fulfill the student innovation and entrepreneurship training plan. Under such a background, colleges and universities have made great efforts in student innovation and entrepreneurship education. However, most of these education projects were carried out independently and there is no systematic design for students' academic study and innovation and entrepreneurship ability. The systematic and layered innovation and entrepreneurship education system will be helpful for cultivating the innovation and entrepreneurship ability for university students.

\section{Characteristics of University Students in Information Science}

Students in information science refer to students majoring in information transmission, processing and storage (including majors of communication and information, computer and information management). Students in information science have some characteristics in thinking mode, study method and innovation practice as follows:

(1) With respect to the thinking mode, students in information science tend to receive more economic information and knowledge in the academic study for meeting the requirement of social and economic development and specialized development. These students are required to grasp the substance of the problem and think divergently. Both solid logical thinking and divergent thinking as well as high innovation and entrepreneurship potential are required in solving problems. [1]

(2) With respect to specialized attainment, students in information science need to be in possession of sturdy information attainment which is manifested in better practice 
ability in information acquisition, processing and application. By utilizing the specialized attainment, university students in information science must find the connection between the advanced technologies and traditional industries to blend information technology into specific industries, which is the mission of university students in information science entrusted by the era.

(3) With respect to the factors of innovation and entrepreneurship, the students should take advantage of the solid information literacy and combine certain aspect of industry, agriculture and service industry to innovate traditional thinking mode, blend in information element and take the initiative in the collection, screening, sorting out and exchange of information relevant to the research subject to apply obtained information to the production practice, make improvement and innovation and improve the innovation ability.

\section{Existing Problems in Innovation and Entrepreneurship Ability Training for Students in Information Science}

\subsection{Low innovation and entrepreneurship ability of students in information science}

The innovation and entrepreneurship ability of students is low in general. Colleges and universities are required to sufficiently realize the problem in a professional manner and establish the innovation and entrepreneurship ability training system applicable to students in information science for the purpose of improving the overall quality.

\subsection{Incomplete innovation and entrepreneurship training mechanism}

The primary cause for the relatively low innovation and entrepreneurship ability of students in information science in overall level is that the students focus on learning knowledge taught in the class and other specialized knowledge while receiving insufficient training in the practice. For solving the problem, the university and division are required to establish complete mechanism involving multiple parties for the purpose of improving the quality of student innovation and entrepreneurship ability training.

\subsection{Lack of scientific and effective student innovation ability evaluation system}

The existing evaluation method lacks students' self-evaluation, which restricts the training and improvement of their independent consciousness. Furthermore, academic score is always the main part for the evaluation. Student qualities are classified into four aspects including ethics, intellect, physique and aesthetics which are given certain weight. The weight of academic score is much higher than that of other aspects. As a result, students with higher academic scores are often evaluated to be excellent. In this way, the innovation ability of students is not manifested and developed. 


\section{Establishment of Innovation and Entrepreneurship Ability Training System for Students in information science}

4.1 Establishment of multi-dimensional systematic design platform to realize cooperative training mechanism

"Systematic platform" means the platform established in multiple dimensions (from class to practice, teacher to student, on campus to off campus) for innovation and entrepreneurship ability training. The intersection and merging of different specialties, link-up training of students in the grade, mutual promotion between teaching and learning and the talent cooperative training between universities and enterprises will be realized through the multi-platform and systematic setting and operation.

4.1.1 Make full use of on-campus and off-campus resources and establish multi-stage innovation supporting platform

In the light of the spirit of the country, and by making use of the university-enterprise cooperation, efforts should be made to facilitate the coordinative development of the multi-level innovation-supporting platform covering the innovation workshop, university student innovation and entrepreneurship project, disciplinary contest and entrepreneur space; cultivate backbone teachers and form professional team to guide students to participate in teachers' scientific research project, social service project, take part in state-level and provincial innovation contests and then strengthen the study motivation and stimulate the innovation activeness of university students through the guidance in projects and contests, thought-inducing questions and project promotion.

4.1.2 Establish platform for supporting teachers' scientific research, teaching research project

Whether teachers are creative in thought and ability has determinative impact on the effect and quality of innovative talent cultivation. [2] Therefore, the platform for supporting teachers' scientific research should be established based on the actual condition of teachers. New resources of the universities may be fully utilized to promote the teamwork. This is an effective way of improving the innovation ability of university students.

4.1.3 Establish training and practice platform under university-enterprise cooperation and explore "blended" faculty establishment mode

The training and practice platform under university-enterprise cooperation should be established by taking the opportunity of university-enterprise cooperation for the purpose of cultivating talents meeting the demand of the society. Through the provision of training and experiment premise for students and organic combination of theory and practice, students will be trained to discover problems and solve problems by using the creativity. In this way, the handling ability, innovation ability and practical ability of students will be tempered and the enterprise, university and students will be benefited. 
4.2 Establish scientific and perfect management system and maximize the resource utilization

\subsubsection{Establish student innovation and entrepreneurship evaluation indicator system}

The evaluation indicator system for innovation and entrepreneurship ability of university students in information science should be studied and established by combing the university student ability training discipline. Through the combination of theory and practice and combination of classroom teaching and outside-classroom practice, the system should be established in the principle of practicability, scientificity and operability.[3,4]

\subsubsection{Establish project, tutor and student excitation mechanism}

Certain management mechanism guaranteeing the benefit of teachers in guiding students in the projects is required for pushing teachers to participate in the training of innovation and entrepreneurship ability of students. If any achievement is made in the projects under the guidance of teachers, reward should be given for the project and to the tutor and students. In this way, teachers and students will maintain the passion and motive force for the innovation and entrepreneurship and the overall level of innovation and entrepreneurship ability training will be improved.

\subsubsection{Standardize project management system}

(1) Standardize the project assessment system.(2) Implement three-stage assessment mechanism. (3) Independent financial management system. (4) Establish archives management system.

4.3 Emphasize the branding project construction and improve the publicity of information science majors

In relation to the disciplinary contest, it is proposed to form the disciplinary contest guidance team, formulate the method of disciplinary contest guidance team management, and study the reform and establishment of law; admit excellent teachers to participate in the disciplinary contest, launch training and cultivation of teachers for disciplinary contest, and retain excellent adviser for disciplinary contest.

As for the innovation and entrepreneurship projects, it is proposed to form innovation and entrepreneurship training reserves mechanism, formulate guide books for teachers and students of innovation and entrepreneurship training project, choose excellent scientific research project and cultivate expert advisor and star students.

\section{References}

[1] Zheng Xiaoyan, Li Yuxia. Comprehensive Evaluation and Analysis of Innovation and Entrepreneurship Ability of University Students of Economics and Management Specialty Based on Analytic Hierarchy Process [J]. Innovation and Entrepreneurship Education, August 2014.

[2] Gao Shuncheng. Study on Multi-dimensional Platform Establishment for Cultivation of Practice and Innovation Ability of Students in Applied Technology-oriented Universities [J]. Journal of Zhengzhou Institute of Aeronautical Industry Management, 2015(4). 140-144. 
[3] Gu Zhun. Establishment and Application of University Student Innovation Ability Evaluation Indicator System [J]. Journal of Yancheng Institute of Technology (Social Science Edition), Edition 1 of March 2015.

[4] Wu Jinhong, Duan Linbo, Wang Shun, Shen Weipeng, Wei Yanjiao. Establishment of University Student's Innovation Ability Measurement Indicator System and Analysis of Improvement Strategy [J]. Science \& Technology Vision. January 2015. 